\title{
The studying of the risk and trends of China's investment in the background of the Belt and Road in Burma
}

\author{
Ruitao Gu \\ Finance School \\ Yunnan University of Finance and Economics \\ Kunming, China \\ 1399259126@qq.com \\ Aiqing Kou \\ International Business School \\ Yunnan University of Finance and Economics
}

\author{
Kunming, China \\ 437805809@qq.com
}

\author{
Jin Chen* \\ Business School \\ Yunnan University of Finance and Economics \\ Kunming, China \\ 644726534@qq.com \\ Corresponding Author
}

\begin{abstract}
In The Belt and Road background, whether it is China or Southeast Asian countries on mutual cooperation and development in the future, reasonable and avoid the risk of investment are very important to both sides, in the process of cooperation, there may be policy, civil war and other factors, so it is very important to study the investment risk and trend, Since 90s, China has become one of the largest investment countries in Burma. It is the focus of investment in all aspects of agriculture and industry. First, it is based on good relations and the demand for future common development. Under the current international situation, resources and labor are the main causes of economic growth. The current Chinese economy, labor resources due to aging, policy control is serious, and Southeast Asian countries is a large population, rich in resources, in Belt and Road Initiative policy above, the state has adopted many policies to promote cooperation, and Southeast Asian countries in the current enterprise technology level is low, and the lack of large enterprises less. Lack of experience, and the development of a country needs consumption, investment, import and export, domestic demand can't keep up, consumption is not good, can only increase investment, increase net export to achieve better development, this is the common need of both sides, so relying on stable cooperation, this is the best development of China and Burma in the future, but also two The well-being of the people of the state in the future. Through good cooperation and good control of the risk, this will enable us to avoid the various risks that exist in the process of development, and thus make better and faster development. In addition, the cheap labor force is urgently needed by the current Chinese enterprises. The increase of labor cost is that many enterprises have lost the power of living, and this is better solved the question through cooperation. This article is devoted to the study of various risks and makes substantive policy recommendations on how to avoid these risks.
\end{abstract}

Keywords-China; foreign direct investment; Burma; geo economy; Southeast Asia; cooperation

\section{INTRODUCTION}

China area along the policy execution, not unfounded, but have had some small investment achieved effect, if you need to the comprehensive development [1], so need to be more popular and get a higher policy support, so the area along the way arises at the historic moment .Under the trend of globalization, replacing weapons [2] with overseas investment, China is increasingly connected with other regions. Southeast Asian countries have made good progress in economic development and become one of the countries in the world. Hot spots for investment. Region adjacent to the sea, back against the landlocked countries, has the good geographical position (Geo Eng economics) was first put forward by American scholar Edward Root Walker, starting from the powers of colonialism, and now are good conditions (1), the early development of embryos for colonialism for southeast Asia, with the precondition that the foreign investment, so it is not the behavior of the sudden, but these investments are established under the colonial powers stripped pressure Fried, not because of mutual benefit and reciprocity of peace [2]. it is also important to have the right methods and to be able to avoid investment risks [3].

In the process of investment, it is necessary to monitor the investment situation of all parties at any time, because the government will have civil unrest at any time. In addition, it is necessary to reach an agreement with all branches of the government to avoid losses [4]. in the process of monitoring and evaluation, only by firmly grasping the actual situation and factors can objective evaluation be carried out, and only by estimating the actual situation can risk assessment be better grasped [5]. track of national policy evaluation has to keep pace with The Times, to avoid the risk, because this is the most need to pay attention to in the present, so the risk, there is no guarantee that the risk, so it is the most important.

*Corresponding author 


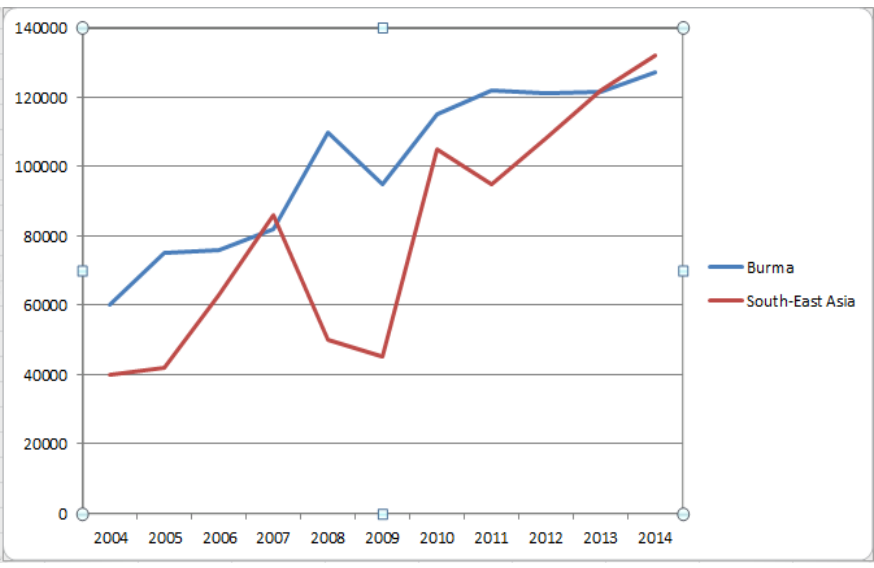

Fig. 1. The investment of southeast Asia and Burma

Can be seen from the figure above, the investment of southeast Asia is red, there are several stages, mainly because of the policy swings, but the general trend is the increasing number of, we can see from among, though halfway down [3], but in general, is growing rapidly.

\section{A BRIEF INTRODUCTION TO MYANMAR'S RESOURCES AND ENVIRONMENT}

\section{A. Myanmar's Resources}

Myanmar is rich in mineral resources, including petroleum, natural gas, tungsten, tin, lead, silver, nickel, antimony, gold, iron, chromium, jade and so on.

Oil is one of Burma's important economic resources. Before the war, oil was myanmar's largest mining industry, producing a maximum of about $1 \mathrm{~m}$ Tonnes a year [4]. In the late $80 \mathrm{~s}$, the open policy, the government has with South Korea, the Netherlands, Australia, Canada, the United States, Japan, the UK's nine oil company signed a contract, respectively in trouble Motta in the shelf, light cotton [5], if open valley and Qin Jiang area oil and gas exploration. According to the energy assessment report of the Asian development bank, there are 104 oil and gas exploration blocks in Myanmar, including 53 inland ones and 51 offshore ones [6]. About 160 million barrels of oil and 20.11 trillion cubic feet of natural gas were measured [7]. Myanmar is one of the most forested countries in the world. In 1994, the total area of Myanmar's forests (including 43\% enclosed forests and 30\% sparse forests) was 34.42 million $\mathrm{hm} 2$, accounting for $51 \%$ [8] of the total land area and $52.3 \%$ of the forest coverage. These resources are of great help to our country.

Myanmar has a rich forest resources, by the mid - 1990 - s, has been found that there are 1347 species of tall tree species, 1696 kinds of 741 kinds of small trees, shrubs, 96 species of bamboo plants, 36 kinds of vine plants and 841 [9] species of flowering plants. Of the 2,088 tree species, 85 have been used in the production of wood for various purposes.

\section{B. Compared with Myanmar's Abundant Resources, China's Resources are Compared with those of some East Asian Countries}

From the east and southeast Asian countries rich in natural resources of the side belong to southeast Asia, because of the seasonal climate, and the particularity of geographic location, lots of resources mainly exist in south-east Asia, first look at China, because of the excessive development [10] of China's natural resources, cause a lot of environmental problems, the government policy mainly take the high speed development into a low speed high quality development, reduce [11] to exploit and utilize resources, the normal demand of resources.

However, cannot be broken, so, can only strengthen the foreign cooperation in the resource-rich countries, look at Japan, it is a developed country, but the land area is narrow, less resources, and industry developed, these resources are highly dependent. In addition, in the information above, we know that Myanmar is rich in forest resources, it is very important in the modern society of manufacturing, we all used paper, household, office, all related to wash it, under the background of the generation of all the way to expand [12] the exchange of these resources, is the development of our country in important ways, after all, the environment of our country is under the influence of rapid development after reform and opening up, is very heavy, so this is also a generation all the way down in our country must cooperate with the increase of Myanmar's state of the objective requirement.

\section{ChinA's InVESTMENT TREND IN MyANMAR}

\section{A. Current Investment Forecast}

We can analyze from the current various forms, the Myanmar for the future investment in China can be a link to central Asia, the Middle East, and the important hub in the developed countries, through the hub for closer cooperation between each other, in addition, under the influence of investment in China, the United States, Britain, the European Union and other countries also strengthened against the investment cooperation, and all this, are all depend on the area under the background of all the way, and China's investments in Burma in addition to the above investment in the resources on the one hand, there are other such as population labor, capital, technology, investment, for example, In domestic universities and Burmese state university for joint training, and do not collect fees to them, also funded, the two outside the domestic each big bank in Burma and joint venture in China to reduce lending rates, this is, of course, under the conditions of legal through risk assessment.

\section{B. How to Build a Harmonious Cooperation Environment}

Rea under the policy guidance of all the way, we need not only to mutual benefit, first of all should make sure is the relationships of each other, not contradictory, and then the development of the economy, if there is no development is good, then everything is futile, there's no way to achieve our goal, then, how should we do, first of all on culture, we want to avoid cultural conflict, must be combined with local 
customs, a lot of what we think the reason should be, are often different in their countries, there is no way to realize, under the condition of free guarantee harmonious, can better and faster to implement. Second, we should cooperate with relevant local enterprises to understand various local supply and demand situations, so that we can better carry out our work and know the difference between ourselves and others. Third, we should seek government protection. Only when it is implemented in a guaranteed way can we achieve stable development, and reduce risks in our investment and cooperation.

\section{Assess Risk Correctly and Effectively}

How to avoid the risk of this problem is one of the focuses of the government and individual entrepreneurs, so first of all we want to see, all the way down in the area, will appear what kind of danger, and what impact will be. First of all, the risk is a direct reason why the loan recovery problems, if can't loan recovery due to exogenous variables, the fracture cause various funds, the enterprise is unsustainable and will make our economic cooperation into crisis, in addition, due to poor financial liquidity due to the economic crisis, according to the traditional technique, the recession will loose monetary policy, but tend to cause more serious economic crisis, to correctly recognize the reasons of economic crisis, is the best way to solve the problem.

\section{At One Belt And One Road, What Should the Government do to Invest in Burma}

Government, as a market leader, to facilitate in various enterprises, first of all should do is with the guide of market rather than the intervention of the market, because in the development of cooperation between China and myanmar, it should be is a question of marketability, if there is excessive government intervention enterprise behavior, might reduce is the vitality of the enterprise, there is no way to live independently, can even survive temporarily, also won't last very long, and the government [13] should do is to maintain the stability of the environment and to solve some factors of insecurity, auxiliary functions [14], is the healthy development of enterprises, in addition, should be pr behavior, the domestic enterprise into Burma, How to improve the efficiency of enterprises, this requires the support and cooperation of local governments, which may bring too much time and other costs, so there is no way to carry out. Therefore, the work of the government seems simple [15] but important, and it is a prerequisite for the friendly and cooperative development of the two countries to reach a good foundation [16] with the Myanmar government. In net exports, our country's trade surplus in recent years, has obtained [17] great achievement, but in these countries, we should keep a good attitude of cooperation, to get the same look forward to the future development.

\section{E. Establishing and Perfecting the System of the Political Risk Assessment and the Early Warning Mechanism}

From another important ways to establish and perfect the system of political risk assessment and early warning mechanism is necessary and helpful, under such a mechanism [18], avoid to bring a lot of economic problems, to solve the political aspect, so the economy will be better, faster implementation [19], the two complement each other, be short of one cannot, less any on the one hand, can make our economic behavior is blocked, so the core of the problem [20] is, how to build, I think I should by experts and scholars to the two countries to work out, only in this way, can we can make our decision [21] more practical, in history, China's support for Burma's armed, etc., and the economy, Have good foundation [22], it is a prerequisite, in terms of early warning mechanism, we should sum up [23] experience, just like that year, and north Korea's cooperation, the final end, there is no substantive effect, so, we should sum up the experiences [24] of the previous, can better after the successful cooperation.

Unrest in the face of Burma policy environment, we should develop a special [25] focus on different categories of departments, so that the high efficient attention and warning, including industrial agriculture and forestry, etc., is the resistance [26], can be a better investment in China and Myanmar have help, adjust measures to local conditions, foster strengths and circumvent weaknesses to domestic mechanism combined with the mechanism of the country, to establish and improve the early warning mechanism [27], guarantee the development of the enterprise, in these conditions are determined, we can continue to do, to reduce the loss of biggest loss, such as war, after all, is unable to recover, once appear, it is difficult to return to their original level, Because after the occurrence, the environment and the original workers are not able to complete the same work as before, and it will be difficult for the new workers without working experience.

\section{China's COPING MeChANISM FOR THE POLITICAL RISKS ENCOUNTERED BY BURMESE INVESTMENT}

From a certain extent, China's investments in Burma is China area along the direction of policy, Chinese investment in Myanmar is a country's diplomatic behavior, so China made investments in Burma. However, from the perspective of Myanmar itself, it is not certain that they can understand it. Just like the reform and opening up of our country in those days, many people do not agree with it and are unwilling to accept it. Due to various problems, not everyone in Myanmar supports China's investment in them. Only by handling these problems can we cooperate in a safe and effective way. In addition, some of the projects in the past, China may indeed some of the credit, the credit to make up, to catch up in the later project, this is difficult, since there is a lot of work to do, the perseverance, more precise to step, more to realize the great Renaissance of the Chinese dream.

The failure of public relations will lead to today's situation. How to live abroad? To show a good self-image in investment and to do a good job in public relations is a necessary condition for enterprises to learn. Only by doing well can we achieve the goal of solidarity and development

\section{REFERENCE}

[1] M. Sparke. From geopolitics to geoeconomics: Transnational state effects in the borderlands [J].Geopolitics, 1998, 3(2):62-98. 
[2] J. E. Rauch. Networks versus markets in international trade[J]. Nber Working Papers, 1999, 48(1):7-35.

[3] W. Zhou. Dynamic and asymmetric contagion reactions of financial markets during the last subprime crisis. Computational Economics, 2017, 50(2): 207-230.

[4] J. M. Levine, C M. D'Antonio. Forecasting Biological Invasions with Increasing International Trade[J]. Conservation Biology, 2003, 17(1):322-326.

[5] G Gandolfo. International Trade Theory and Policy[J]. Springer Texts in Business \& Economics, 2017, 34(35):169-181.

[6] W. Zhou, Z. Xu. Probability calculation and element optimization of probabilistic hesitant fuzzy preference relations based on expected consistency. IEEE Transactions on Fuzzy Systems, 2018, 26(3): 1367-1378.

[7] R. Findlay, M. Lundahl. International Trade and Factor Mobility with an Endogenous Land Frontier: Some General Equilibrium Implications of Christopher Columbus[M]// The Economics of the Frontier. Palgrave Macmillan UK, 2017.

[8] Zhang Q, Jiang X, Tong D, et al. Transboundary health impacts of transported global air pollution and international trade[J]. Nature, 2017, 543(7647):705

[9] W. Zhou, J. He. Generalized GM $(1,1)$ model and its application in forecasting of fuel production. Applied Mathematical Modelling, 2013, 37(9): 6234-6243.

[10] K J. Vandevelde. Abandoning the International Trade Organization: U.S. Postwar Friendship, Commerce, and Navigation Treaties[M]// The First Bilateral Investment Treaties. 2017.

[11] W. Zhou, Z. Xu. Generalized asymmetric linguistic term set and its application to qualitative decision making involving risk appetites. European Journal of Operational Research, 2016, 254: 610-621.

[12] Y. Ono, Y D. Kim, N. Itsubo, et al. A Country-Specific Water Consumption Inventory Considering International Trade in Asian Countries Using a Multi-Regional Input-Output Table[J]. Sustainability, 2017, 9(8):1351

[13] W. Zhou, Z. Xu. Generalized asymmetric linguistic term set and its application to qualitative decision making involving risk appetites. European Journal of Operational Research, 2016, 254: 610-621.

[14] Y. Xiao, J. Murray, M. Lenzen. International trade linked with disease burden from airborne particulate pollution[J]. Resources Conservation \& Recycling, 2017, 129:1-11.
[15] T. Gorcheva. The agreements of the Paris conference on yhe control of climate changens and the impact on international trade $[\mathrm{J}]$. Economic Thought Journal, 2017.

[16] K. Dasgupta , J. Mondria. Quality Uncertainty and Intermediation in International Trade $\hat{\sim}[\mathrm{J}]$. Working Papers, 2018

[17] W. Zhou, Z. Xu. Portfolio selection and risk investment under the hesitant fuzzy environment. Knowledge-Based Systems, 2018. 144: 21-31.

[18] F. Reganati, P. Rosanna, T. Luca. How to detect illegal waste shipments? The case of the international trade in polyethylene waste[J]. Economics Bulletin, 2017, 37(4):2625-2640.

[19] W. Zhou, Z. Xu. Group consistency and group decision making unde uncertain probabilistic hesitant fuzzy preference environment. Information Sciences, 2017, 414: 276-288

[20] F. Faisal, T. Tursoy, N G. Resatoglu N G. Linkage between international trade, financial development and economic growth in Saudi Arabia: An application of the combined cointegration approach[J]. Journal of Management Sciences, 2017, 4.

[21] Z. Jiang. On the connotation and extension of species concept used by the Convention on International Trade in Endangered Species of Wild Fauna and Flora (CITES)[J]. Biodiversity Science, 2017, 25(1):72-79.

[22] A. Schra, A. Ruckert, A. Vanduzer, et al. A conceptual framework for investigating the impacts of international trade and investment agreements on noncommunicable disease risk factors[J]. Health Policy \& Planning, 2017.

[23] R. Ivory. Corruption Gone Wild: Transnational Criminal Law and the International Trade in Endangered Species[J]. 2017, 111:413-418.

[24] H. Chen. International trade, property maintenance intensity and renewable resources sustainability $[\mathrm{J}]$. Advances in Modelling \& Analysis A, 2017, 54(1):1-20.

[25] M. Bahmani-Oskooee, A. Gelan. Exchange-rate volatility and international trade performance: Evidence from 12 African countries[J] Mpra Paper, 2017.

[26] A. Akerman. A theory on the role of wholesalers in international trade based on economies of scope[J]. Research Papers in Economics, 2018 , 51(1).

[27] J M. Levine, C M. D'Antonio. Forecasting Biological Invasions with Increasing International Trade $[\mathrm{J}]$. Conservation Biology, 2003, 17(1):322-326 